
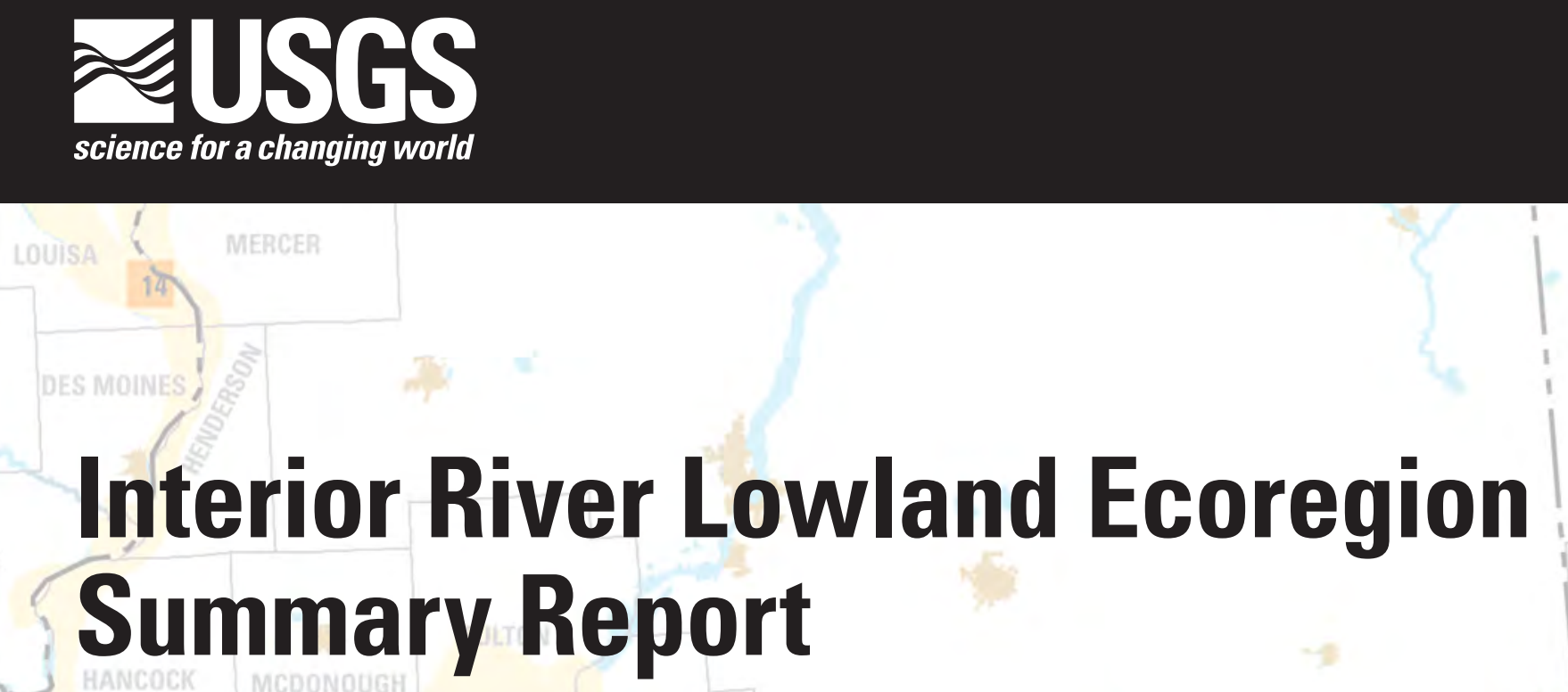

Open-File Report 2008-1088

U.S. Department of the Interior U.S. Geological Survey 
Cover. Map showing the Interior River Lowlands Ecoregion 


\section{Interior River Lowland Ecoregion Summary Report}

By Krista A. Karstensen

Open-File Report 2008-1088

U.S. Department of the Interior

U.S. Geological Survey 


\section{U.S. Department of the Interior DIRK KEMPTHORNE, Secretary}

\section{U.S. Geological Survey \\ Mark D. Myers, Director}

\section{U.S. Geological Survey, Reston, Virginia: 2008}

For product and ordering information:

World Wide Web: http://www.usgs.gov/pubprod

Telephone: 1-888-ASK-USGS

For more information on the USGS--the Federal source for science about the Earth, its natural and living resources, natural hazards, and the environment:

World Wide Web: http://www.usgs.gov

Telephone: 1-888-ASK-USGS

Any use of trade, product, or firm names is for descriptive purposes only and does not imply endorsement by the U.S. Government.

Although this report is in the public domain, permission must be secured from the individual copyright owners to reproduce any copyrighted materials contained within this report.

Suggested citation:

Karstensen, K.A., 2008, Interior River Lowland Ecoregion Summary Report: U.S. Geological Survey Open-File Report 2008-1088, 5 p. 


\section{Contents}

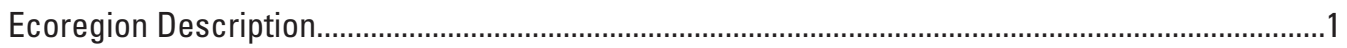

Contemporary Land-Cover Change (1973-2000) .............................................................................

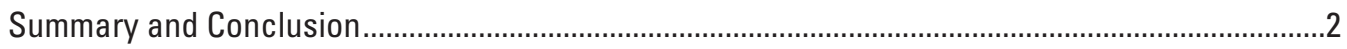

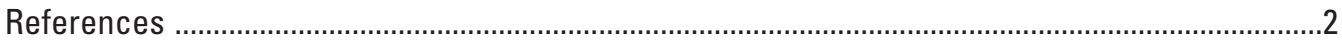

\section{Figures}

1. Map showing the Interior River Lowlands Ecoregion .......................................................

2. Bar chart showing net land-cover changes in the Interior River Lowlands during each

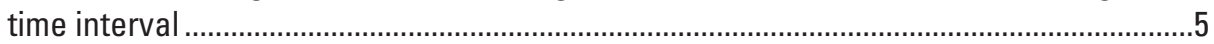

\section{Tables}

1. The estimated overall spatial change in the Interior River Lowland Ecoregion between

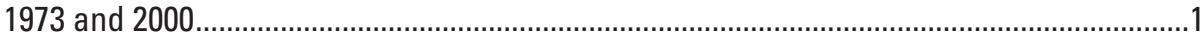

2. The total and annual rates of land-cover change for each time interval .........................1

3. The estimated land-cover area for each land-use and land-cover class between 1973

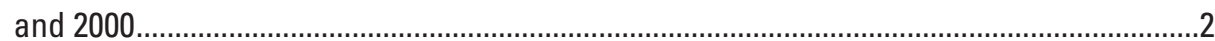

4. The leading land-cover conversions for the four time intervals of the Interior River Lowland Ecoregion from 1973-2000 ............................................................................... 



\title{
Interior River Lowland Ecoregion Summary Report
}

\author{
By Krista A. Karstensen
}

\section{Ecoregion Description}

The Interior River Lowlands ecoregion encompasses 93,200 square kilometers $\left(\mathrm{km}^{2}\right)$ across southern and western Illinois, southwest Indiana, east-central Missouri, and fractions of northwest Kentucky and southeast Iowa (fig 1). The ecoregion includes the confluence areas of the Mississippi, Missouri, Ohio, Illinois, and Wabash Rivers, and their tributaries.

This ecoregion was formed in non-resident, non-calcareous sedimentary rock (U.S. Environmental Protection Agency, 2006). The unstratified soil deposits present north of the White River in Indiana are evidence that pre-Wisconsinan ice once covered much of the Interior River Lowlands. The geomorphic characteristics of this area also include terraced valleys filled with alluvium as well as outwash, acolian, and lacustrine deposits.

Historically, agricultural land use has been a vital economic resource for this region. The drained alluvial soils are farmed for feed grains and soybeans, whereas the valley uplands also are used for forage crops, pasture, woodlots, mixed farming, and livestock (USEPA, 2006). This ecoregion provides a key component of national energy resources as it contains the second largest coal reserve in the United States, and the largest reserve of bituminous coal (Varanka and Shaver, 2007). One of the primary reasons for change in the ecoregion is urbanization.

\section{Contemporary Land-Cover Change (1973-2000)}

From 1973-2000, 5.60 percent of the total study area land cover changed at least once. This change in the ecoregion is known as the footprint. An estimated 5 percent of the ecoregion underwent change once (table 1). The percentage of the ecoregion that underwent multiple changes was low; 0.60

Table 1. The estimated overall spatial change in the Interior River Lowland Ecoregion between 1973 and 2000.

\begin{tabular}{lclllll}
\hline & $\begin{array}{c}\text { Overall spatial } \\
\text { change }\end{array}$ & \multicolumn{4}{c}{ Number of changes } \\
\hline Percent of ecoregion & 5.6 & 1 & 2 & 3 & 4 \\
\hline
\end{tabular}

percent of the area changed twice, 0.10 percent changed three times.

Annual rates of change peaked from 1973 to 1980 with 1.84 percent change and slowly declined until a slight peak from 1992 to 2000, with a 1.75 percent change (table 2). All of the change estimates have an associated margin of error of less than plus or minus 0.80 percent. The margin of error varied directly with the percent change in that it decreased with the lower amount of change from 1980 to 1986 and 1986 to1992, and increased slightly between 1992 and 2000. When normalized to the annual rate of change, the land-cover change again declined after 1980 before increasing again between 1992 to 2000. During the study period, the conversions from forest land to agricultural land and agricultural land to developed land dominated the land-cover change.

Table 2. The total and annual rates of land-cover change for each time interval.

[+/-; plus or minus]

\begin{tabular}{lcccc}
\hline & \multicolumn{4}{c}{ Period } \\
\cline { 2 - 5 } & $\mathbf{1 9 7 3 - 1 9 8 0}$ & $\mathbf{1 9 8 0}-\mathbf{1 9 8 6}$ & $\mathbf{1 9 8 6}-\mathbf{1 9 9 2}$ & $\mathbf{1 9 9 2 - 2 0 0 0}$ \\
\hline $\begin{array}{c}\text { Total change (percent of } \\
\text { ecoregion) }\end{array}$ & 1.84 & 1.37 & 1.17 & 1.75 \\
$\begin{array}{c}\text { Margin of error (85 } \\
\text { percent confidence } \\
\quad \text { level) }\end{array}$ & $+/-0.706$ & $+/-0.389$ & $+/-0.378$ & $+/-0.688$ \\
$\begin{array}{c}\text { Average annual rate of } \\
\text { change (percent/year) }\end{array}$ & 0.48 & 0.27 & 0.26 & \\
\hline
\end{tabular}

The overall spatial land-cover change in percent of regional area between land-use categories during the study period is significant. Although agriculture is the primary land cover in this ecoregion, the analysis indicated that cropland use is intense, and urbanization is expanding, based on several economic sectors and industries (Varanka and Shaver, 2007). Agriculture is the primary land use; it comprised 65.0 percent of the ecoregion but declined marginally to 64.7 percent in 2000 (table 3). Forest was the next highest land cover-type, 22.7 percent in 1973, and 20.4 percent in 2000 (table 3). Developed land had a small, but steady gain, from 5.37 percent in 1973 to 6.98 percent in 2000.

Developed land expanded the most, with an increase of 1.61 percent between 1973 and 2000 (table 3). The largest net loss occurred in forest land cover, with net declines of 2.27 percent. Development generally decelerated during the study period (fig. 2), before peaking with the greatest rate of expan- 
Table 3. The estimated land-cover area for each land-use and land-cover class between 1973 and 2000.

[ $\mathrm{km}^{2}$, square kilometers; -, negative]

\begin{tabular}{|c|c|c|c|c|c|c|c|c|c|c|c|c|}
\hline \multirow[b]{2}{*}{ Land-use class } & \multicolumn{2}{|c|}{1973} & \multicolumn{2}{|c|}{1980} & \multicolumn{2}{|c|}{1986} & \multicolumn{2}{|c|}{1992} & \multicolumn{2}{|c|}{2000} & \multicolumn{2}{|c|}{$\begin{array}{c}\text { Net Change } \\
1973-2000\end{array}$} \\
\hline & $\mathbf{k m}^{2}$ & Percent & $\mathbf{k m}^{2}$ & Percent & $\mathbf{k m}^{2}$ & Percent & $\mathbf{k m}^{2}$ & Percent & $\mathbf{k m}^{2}$ & Percent & $\mathbf{k m}^{2}$ & Percent \\
\hline Water & 2,460 & 2.64 & 2,520 & 2.70 & 2,520 & 2.70 & 2,560 & 2.75 & 2,620 & 2.80 & 160 & 0.16 \\
\hline Developed & 5,010 & 5.37 & 5,400 & 5.79 & 5,580 & 5.98 & 5,790 & 6.24 & 6,510 & 6.98 & 1,500 & 1.61 \\
\hline Mechanically disturbed & 103 & 0.11 & 80.9 & 0.09 & 30.4 & 0.03 & 20.5 & 0.02 & 14.9 & 0.02 & -88.0 & -0.09 \\
\hline Mining & 118 & 0.13 & 91.6 & 0.10 & 128 & 0.14 & 222 & 0.24 & 99.8 & 0.11 & -18.5 & -0.02 \\
\hline Natural Bare & 15.4 & 0.02 & 15.4 & 0.02 & 15.4 & 0.02 & 17.0 & 0.02 & 22.2 & 0.02 & 6.80 & 0.00 \\
\hline Forest & 21,200 & 22.7 & 20,300 & 21.8 & 19,700 & 21.2 & 19,300 & 20.7 & 19,100 & 20.4 & $-2,100$ & -2.27 \\
\hline Grass/Shrub & 470 & 0.50 & 414 & 0.44 & 396 & 0.42 & 417 & 0.45 & 408 & 0.44 & -61.6 & -0.06 \\
\hline Agriculture & 59,700 & 64.0 & 60,200 & 64.60 & 60,700 & 65.0 & 60,700 & 65.1 & 60,300 & 64.7 & 600 & 0.66 \\
\hline Wetland & 4,250 & 4.55 & 4,240 & 4.54 & 4,210 & 4.51 & 4,210 & 4.52 & 4,250 & 4.56 & 0.30 & 0.01 \\
\hline $\begin{array}{l}\text { Non-mechanically } \\
\text { disturbed }\end{array}$ & 0.00 & 0.00 & 0.00 & 0.00 & 0.00 & 0.00 & 0.00 & 0.00 & 0.00 & 0.00 & 0.00 & 0.00 \\
\hline
\end{tabular}

sion between 1992 and 2000, which is also the period with the second highest overall rate of ecoregion change (1.75 percent).

The five most common land cover conversions are illustrated in table 4. Overall, the greatest change during the study period was the conversion from forest to agriculture. Between 1973 and 2000, the most common conversion $\left(2,110 \mathrm{~km}^{2}\right)$ was from forest cover to agriculture (table 4); however, this conversion did not result in a net increase in agriculture because during the same time, agricultural lands were being converted to developed land. Conversion from agriculture to developed land was the second most common change $\left(1,190 \mathrm{~km}^{2}\right)$. The loss of agricultural land cover was masked by a low net amount of change (0.66 percent).

\section{Summary and Conclusion}

The study categorized the Interior River Lowland as a rich natural environment with a low to moderate demand for competing land uses, despite a relatively low population, that maintains the stability and growth of the region (Varanka and Shaver, 2007). Because of the lack of any statistical analysis of neighboring ecoregions, it is recommended that a comparative analysis to adjoining ecoregions be conducted at a later date.

\section{References}

Environmental Systems Research Institute, Inc. data and maps- 2006: Environmental Systems Research Institute, Inc., scale 1:100,000.

United States Environmental Protection Agency, 2006, Ecoregions of Indiana and Ohio: accessed July 31, 2007, http:// www.epa.gov/wed/pages/ecoregions/ohin_eco.htm

Varanka, Dalia E., and Shaver, David K., 2007, Land-use change trends in the Interior River Lowlands Ecoregion: U.S. Geological Survey Scientific Investigations Report 2007-5145, $12 \mathrm{p}$. 
Table 4. The leading land cover conversions for the four time intervals of the Interior River Lowland Ecoregion from 1973-2000.

[km², square kilometers]

\begin{tabular}{|c|c|c|c|c|}
\hline Period & From Class & To Class & Area changed $\left(\mathbf{k m}^{2}\right)$ & Percent of all changes \\
\hline \multirow[t]{7}{*}{ 1973-1980 } & Forest & Agriculture & 856 & 54.0 \\
\hline & Agriculture & Developed & 304 & 19.0 \\
\hline & Forest & Mechanically Disturbed & 59.0 & 4.00 \\
\hline & Grassland/Shrubland & Forest & 58.0 & 4.00 \\
\hline & Agriculture & Forest & 57.0 & 4.00 \\
\hline & Other Classes & Other Classes & 244 & 15.0 \\
\hline & Total & & 1,580 & 100 \\
\hline \multirow[t]{7}{*}{ 1980-1986 } & Forest & Agriculture & 603 & 52.0 \\
\hline & Agriculture & Developed & 138 & 12.0 \\
\hline & Wetland & Agriculture & 103 & 9.00 \\
\hline & Grassland/Shrubland & Forest & 65.0 & 5.00 \\
\hline & Agriculture & Wetland & 48.0 & 4.00 \\
\hline & Other Classes & Other Classes & 205 & 18.0 \\
\hline & Total & & 1,160 & 100 \\
\hline \multirow[t]{7}{*}{ 1986-1992 } & Forest & Agriculture & 409 & 42.0 \\
\hline & Agriculture & Developed & 170 & 14.0 \\
\hline & Agriculture & Mining & 143 & 15.0 \\
\hline & Mining & Agriculture & 43.0 & 4.00 \\
\hline & Forest & Developed & 42.0 & 4.00 \\
\hline & Other Classes & Other Classes & 175 & 18.0 \\
\hline & Total & & 982 & 100 \\
\hline \multirow[t]{7}{*}{ 1992-2000 } & Agriculture & Developed & 574 & 37.0 \\
\hline & Forest & Agriculture & 245 & 16.0 \\
\hline & Mining & Agriculture & 139 & 9.00 \\
\hline & Forest & Developed & 120 & 8.00 \\
\hline & Agriculture & Forest & 119 & 8.00 \\
\hline & Other Classes & Other Classes & 336 & 22.0 \\
\hline & Total & & 1,530 & 100 \\
\hline \multirow[t]{7}{*}{ 1973-2000 } & Forest & Agriculture & 2,110 & 42.0 \\
\hline & Agriculture & Developed & 1,190 & 24.0 \\
\hline & Forest & Developed & 243 & 5.00 \\
\hline & Agriculture & Forest & 236 & 5.00 \\
\hline & Agriculture & Mining & 210 & 4.00 \\
\hline & Other Classes & Other Classes & 980 & 20.0 \\
\hline & Total & & 4,970 & 100 \\
\hline
\end{tabular}




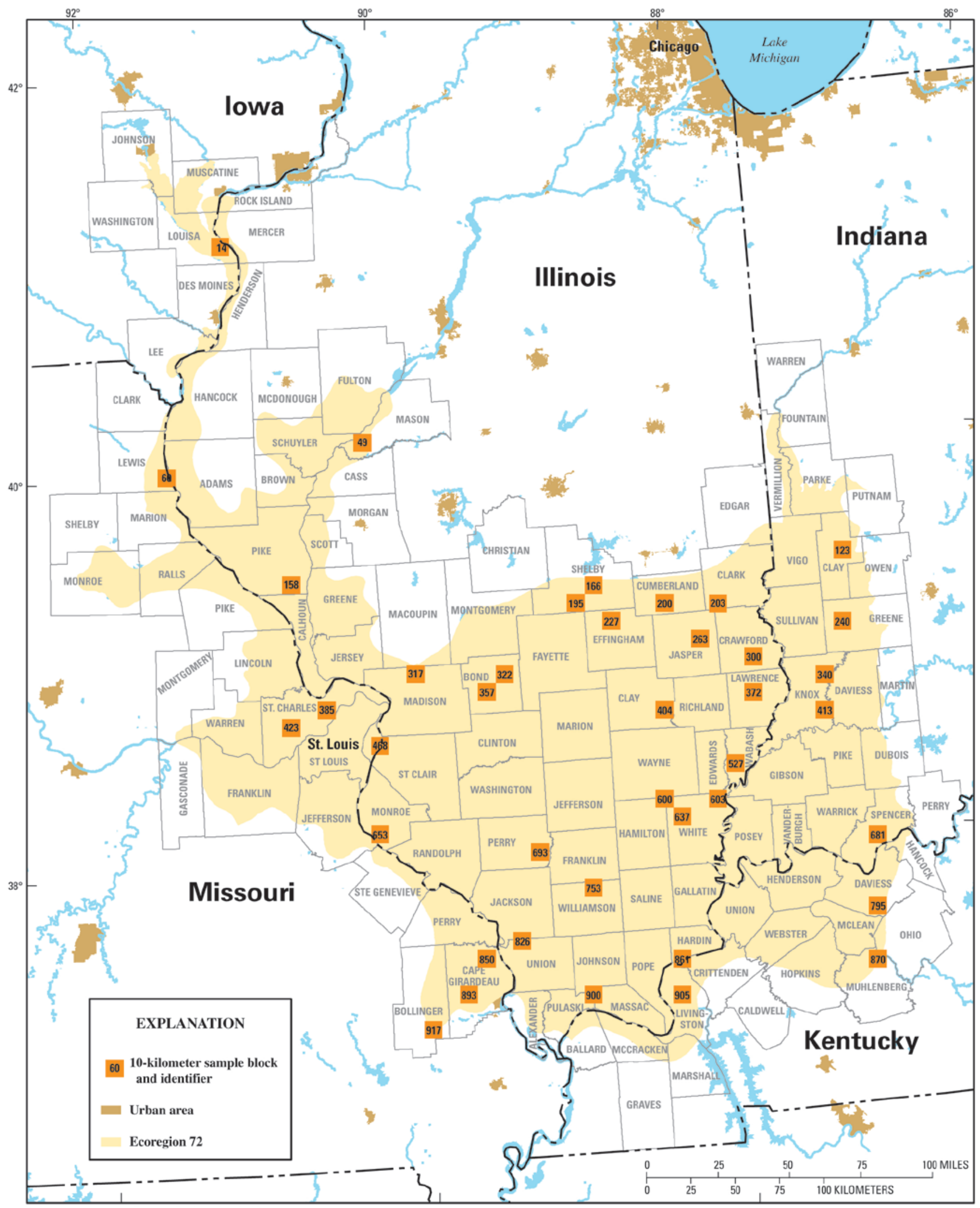

Environmental Systems Research Institute, Inc. (ESRI)

Data and Maps, 2006

Figure 1. The Interior River Lowlands Ecoregion. 

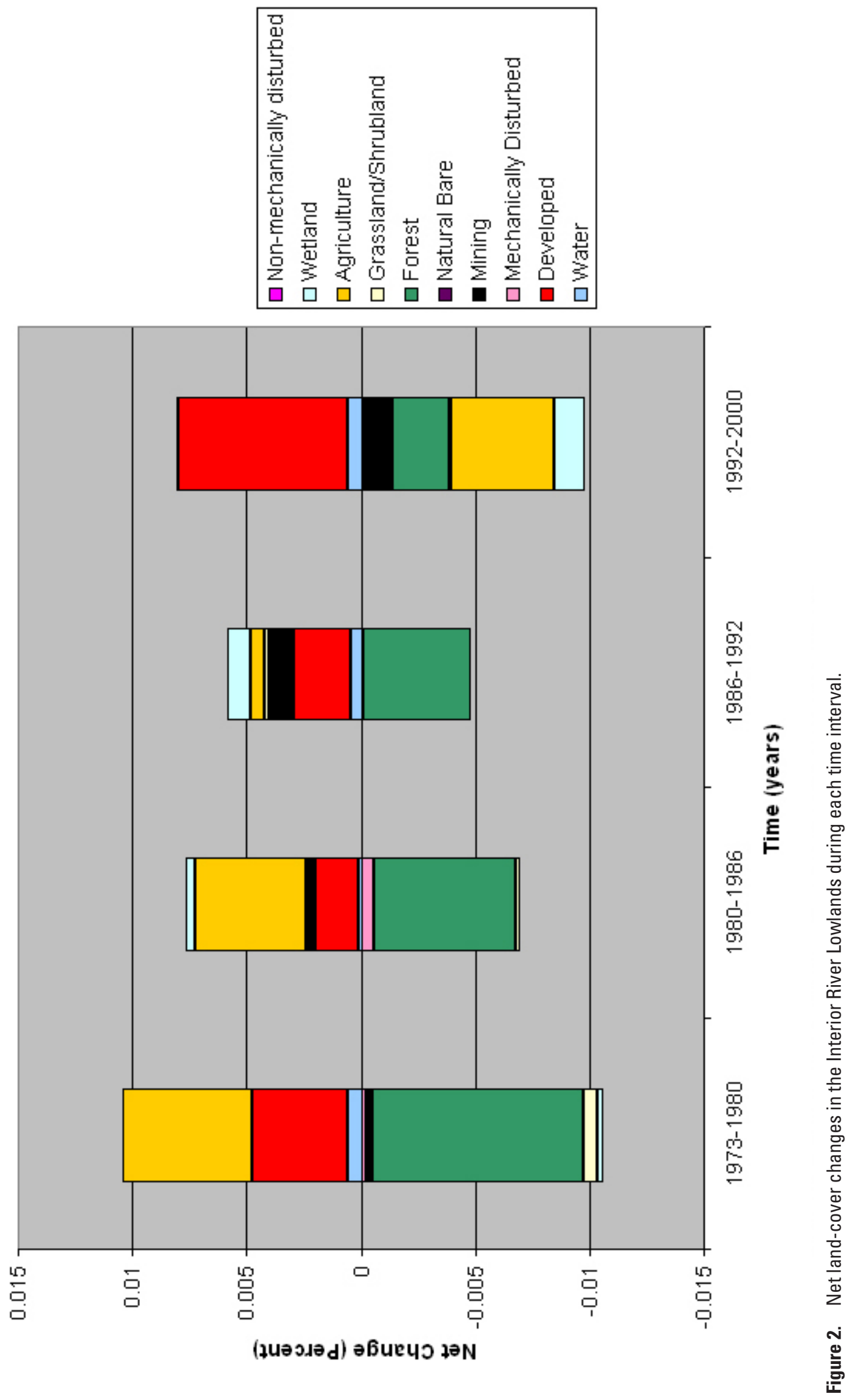
Publishing support provided by:

Rolla Publishing Service Center

For more information concerning this publication, contact: Director, USGS Mid-Continent Geographic Science Center 1400 Independence Road

Rolla, MO 65401

(573) 308-3652

Or visit the Mid-Continent Geographic Science Center Web site at: http://mcgsc.usgs.gov 



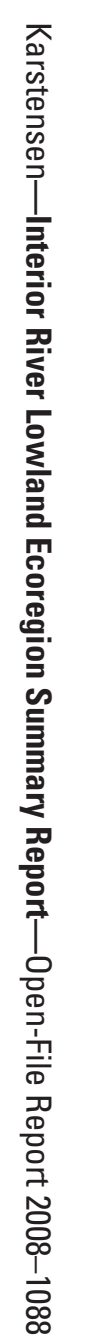

8 Printed on recycled paper 